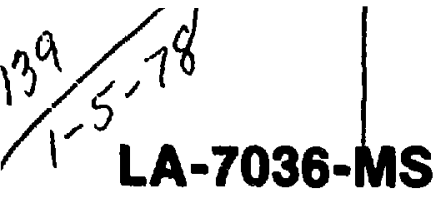

Informal Report
UC-80

Issued: November 1977

\title{
Neutronics of a Mixed-Flow Gas-Core Reactor
}

\author{
Patrick D. Soran \\ Gordon E. Hansen
}

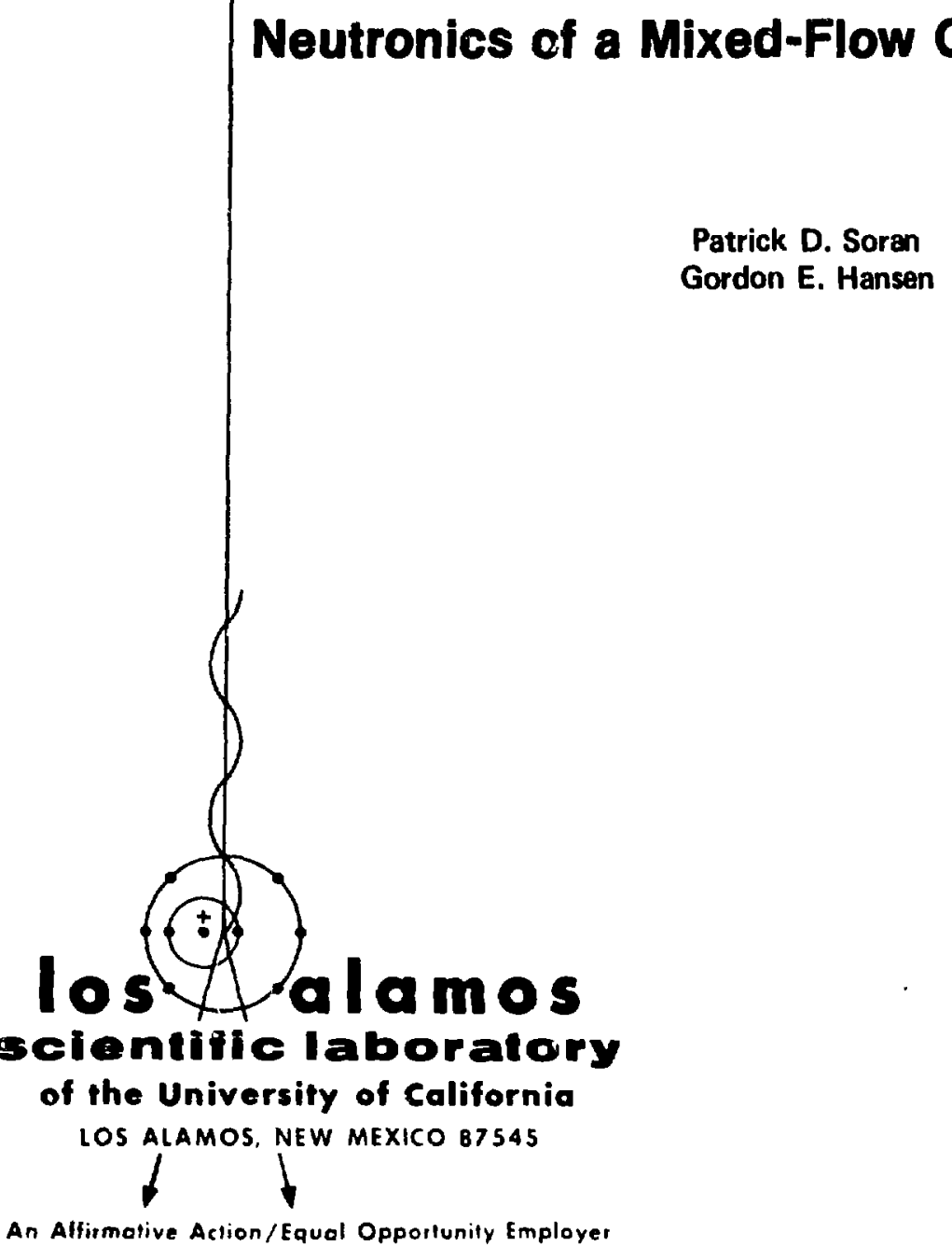

\footnotetext{
An Alfirmative Action / Equal Opporfunity Employer
} 
ABSTRACT . . . . . . . . . . . . . . . . . . . . . . . 1

I. SUMMARY . . . . . . . . . . . . . . . . . . . . 1

II. NEUTRONIC ANALYSIS . . . . . . . . . . . . . . . . . . 3

A. Calculational Techniques . . . . . . . . . . . . . . 3

1. Monte Carlo Code ................... 3

2. Nuclear Data and Reactions... . . . . . . . . . 3

3. Thermal Neutrons................... . 4

4. Calculation Methodology ................ 4

B. Four-Cell Radial Reactor .. . . . . . . . . . . . . 5

1. Calculational Results ................. 5

2. Conclusions ................... 6

C. Seven-Cell Radial Reactor . . . . . . . . . . . . 6

1. Calculational Results ................ . 6

2. Conclision.................... 6

D. Seven-Cell Scallop Reactor . . . . . . . . . . . . 6

1. Calculational Results . . . . . . . . . . . 8

2. Conclusion .... . . . . . . . . . . . . . 8

E. Discussion of Seven-Cell Reactors ... . . . . . . . . . . 8

III. CONCLUSIONS . . . . . . . . . . . . . . . . . . . . . 10

ACKNOWLEDGMENTS . . . . . . . . . . . . . . . . . . . . . . 10

REFERENCES . . . . . . . . . . . . . . . . . . . . . . . . . . . 12

APPENDIX A Nuclear Densities in Mixed-Flow Gas Reactor . . . . . . . . 12

APPENDIX B Faur-Cell Mixed-Flow Gas-Core Analysis . . . . . . . . . . 13

APPENDIX C Seven-Cell Mixed-Flow Gas-Core Analysis . . . . . . . . . . 13

APPENDIX D Interpolation Algorithr and Results . . . . . . . . . . 16

\section{FIGURES}

1. Mixed-flow reactor radial cross section . . . . . . . . . . . 11

2. Mass of beryllium vs conversion ratio . . . . . . . . . . . 11

3. Mass of beryllium vs clean critical mass. . . . . . . . . . . . . 11

4. Web 2 thickness vs power ratio... . . . . . . . . . . . . . 11

\section{TABLES}

I. Four-Ce11 U-233-Loaded Radial Reactor . . . . . . . . . . . 7

II. Seven-Cell Radial Reac! or . . . . . . . . . . . . . 7

III. Seven-Cell Scallop Reactor . . . . . . . . . . . . . . . 9 
Patrick D. Soran and Gordon E. Hansen

\begin{abstract}
Th1s study was made to Investigate the reutronic feasibility of a mixed-flow gas-core reactor. Three reactor concepts were studied: four-and seven-cell radlal reactors and a seven-cell scallop reactor. The reactors were fueled with $\mathrm{UF}_{6}$ (elther $\mathrm{U}-233$ or $\mathrm{j}-235$ ) and varlous parameters were varled. A four-cell reactor is not practical nor is the U-235 fueled seven-cell radial reactor; however, the 7-cell U-233 radial and scallop reactors can satisfy all design criterla. The mixed flow gas core reactor is a very attractive reactor concept and warrants further investigation.
\end{abstract}

\title{
I. SUMMARY
}

Several problems face future reactor designers. One concerns nonproliferation -- transurantum actinides can be used in weapons. Another concerns more efficient use of the world's uranium resources. Yet another concerns nuclear waste management. These problems will not be Immediately solved, but they are beting addressed by a Los Alamos Sclentific Laboratory (LASL) study ${ }^{1}$ of a seif-contained electrical generating system which contains heat exchangers, turbo-generators, fuel processing and reprocessing equipment, and approprlate waste removal equipment. At the heart of this energy system is a high-temperature gas-core nuclear reactor. The neutronic analysis of the gascore reactor is the subject of this report.

As a practical matter, a multi-cell reactor was chosen to consist of $1-m-$ diameter by 4.3-m-length fuel cans filled with uranium hexafluoride (elther U-233 or U-235) gais at $1000 \mathrm{~K}$. The fuel cans are embedded in a Be matrix which 
acts as moderator and reflector. Beyond the Be region is a molten thorfum salt for the production of U-233 to be used as reactor fuel.

Three different reactor geometrles have been studied. A "radlal" reactor with four fuel cells, a "radlal" reactor with seven fuel cells, and a "scallop" reactor with seven fuel cells. The "radlal" reactor consists of fuel cells erabedded in a circular-cylinder of Be. One fuel cell 18 located in the center of the Be matrix and the remaining 3 or 6 cells have $3 / 2 \pi$ and $6 / 2 \pi$ angular symmetry, respectively. The "scallop" reactor is the same except that the Be radial surface is scailoped to maintain a constant thickness beyond the peripheral fuel celis. Figure 1 is the top view of one of the 7-fuel-cell "scallop" reactor configurations which were analyzed in this study. In all cases the top and bottom Be surface $1 \mathrm{~s}$ flat and there is top-bottom reflection symmetry. The geometrles are completely specified by three parameters: $W 1$, the separation distance between adjacent gas cylinders; W2, the Be thickness beyond the periphejal gas cylinders; and $T$, the slab thickness above and below the fuel gas. We exunined the effects of $W 1$, $W 2$, and $T$ dimensions on the fuel inventory, the $B e$ Inventory, the power distributions, and the reactor's breeding ability.

A 4-cell U-233 or U-235 loaded reactor is not viable. If W1, W2, and $T$ are adjusted to yleld a critical system, there is not sufficient neutron leakage: for breeding. Although several $\mathrm{W} 1, \mathrm{~W} 2$, and $\mathrm{T}$ parameter studies were performed; the concept was abandoned since the reactor could not satisfy all design criteria.

Both the 7-cell U-233 loaded "radial" and "scallop" reactors could satisfy all design criteria by :,roper selection of W1, W2, and T. Although conversion ratios for optimum U-235 scallop reactor were less than unfty, the ratios were large enough to maintain criticality as the cores were rep] enished with the U-233 produced. For fixed W1, W2, and T the "scallop" reactr uses less Be and has a higher breeding ratio than the "radial" reactor. Using elther U-235 or U-233 loaded "radlal" or "scallop" core 3 , we have determined the clean critical mass as a function of Be mass, the breeding ratio as a function of Be mass, the central/outer cell power ratios as a function of W2 and the central/outer power ratio as a functlor of fuel gas iensities. For a workable configuration, the gas-core reactor system requires a:proximately a factor of 10 less fuel inventory than that of a comparable colventional reactor. 
In summary, the neutronic analysis of the non-proliferation gas-core reactor has 1 i d us to conclude that it is a very attractive reactor concept that warrants further research.

\section{NEUTRONIC AIALYSIS}

MONK. ${ }^{2}$ This LASL code calculated the $k_{e f f}$ of the various reactor configurations In addition t' power distributions, fractional neutron leakage, and other flux tallies. A free gas kernel in the MCNK code described the thermal neutron interaction with the Be. The LASL master Monte Carlo library was the source of the continuous energy neutror cross-sections. ${ }^{3}$

A. Calculational Techniques

1. Monte Carlo Code. The Monte Carlo code used for criticality studies at LASL is the continuous energy code MCNK. A modification of MCN, the MCNK code contains essentially the same input, collision routine, biasing techniques, and general geometry package as the MCN code. The MCNK program is an iterative scheme for finding the multiplication in a statc configuration contafing fissile materials. From a given fission source the code transports the neutrons, creating a new fission source. The procedure is 1terative, using the latest distribution as the source for a new cycle until convergence is attained. An estimate of the multiplication constant $k_{\text {ef }}$ is obtained from a ratio of the neutron population in the $(n+1)$ st generation to that in the nth generation. The source is self-correctlve in the sense that if the user decides to use a source of $\mathrm{N}$ particles, then the code generates a new source of approximately $\mathrm{N}$ neutrons. The total weight started from the source at the beginning of each cycle remains constant.

One of the advantages of the MCNK code is that neutron data are handled in a continuous energy sense. The cross sections are read into the code in considerable detall in an attempt to use the information with no significant approximation or distortions.

2. Nuclear Data and Reactions. The pointwise neutron cross sectlons are provided at discrete energies and are tabulated in the Monte Carlo 1ibrary on an energy grid that is tailored to each isotope. Linear interpolation is used between energy points, with a few hundred to several thousand points typically required. For each isotope, cross sections are added at a sufficlent number of 
points to insure that the linear interpolation constratnt reproduces the original cross-section tabulation within a specified tolerance. Furthermore, the energies at which the cross sections are tabulated are unionized so that all reactions are given the same energy grid.

All reactions given in a particular cross-section evaluation (such as ENDL, or ENDF/B) are accounted for. Users have the cholce of three sources of cross sections for most 1sotopes: ENDF/B-IV, ENDL from LLL, and the British (AWRE) Itbrary. Resonance parameters, if they are given in the evaluation, are processed at several temperatures and added to the pointwise cross sections. Data for the energy distribution of secondary neutrons are used directly in terms of the "laws" prescribed in the particular cross-section evaluation. Ingular distributions for elastic and inelastic scattering events are stored in the Monte Carlo library for 32 equally probable bins on a fine grid of incident neutron energies.

Because of the cross-section representation in a continuous manner, neutrons which slow down from the $\mathrm{MeV}$ to eV region undergo proper shielding effects in the resolved resonance energy region. Thus there is no need for self-shielding corrections in this energy region. There is no rigorous unresolved resonance treatment in MCNK; however, for this study the unrcsolved energy region is of minor concern.

3. Thermal Neutrons. The MCNK code includes a thermalization routine employing the free gas model. Below a thermal cut-in energy, the lighter atoms are assumed to be thermal motion, with a Maxwellian distribution of velocities determined by the thermal temperature of the region. Each cell of the protlem has it; own thermal temperature. Scattering from the light nuclei includes the effect of thermal motion. For nuclei belonging to the heavier groups of atoms, elastic scattering is assumed to occur categorlcally in the laboratory system, with no energy loss.

4. Calculation Methodology. The fission source was defined by starting 500 neutrons in the center of each fuel can. After approximately 15 cycles the calculation was stopped and the fission source was saved. This fission source distribution was used as the initial fission source estimate for all subsequent keff calculations.

The Monte Carlo used calculations He, Be, F, U-233, U-235, and U-238 cross sections. The thermal neutron treatment was implemented for Be. All calculations used between 60-100 thousand particles and produced a statistical 
$k_{\text {eff }}$ with a relative error less than $3 \%$. In the case of energy deposition tallies in MCNK, the statistics were done with a relative error less than $5 \%$.

Several geometric propertles are common to all the reactor concepts. Each fuel cell is $1 \mathrm{~m} 1 \mathrm{n}$ dianeter and $4.3 \mathrm{~m}$ in length. The fuel cell is divided radially into two regions: the central region is $0.75 \mathrm{~m}$ in diameter and the outer region is the remaining: $0.25 \mathrm{~m}$. This modeling accounts for the central hot-fuel region and the outer gas-fuel Buffer region as described in Ref. 1. For all reactors the top and bottom Be surface is flat and there is top-bottom reflection symmetry. The geometries are completely specified by three parameters: W1, the separation distance adjacent gas cylinders; W2, the Be thickness beyond the peripheral gas cylinder; and $T$, the slab thickness above and below the fuel gas. The effect of W1, W2, and $T$ dimensions on $k$ eff total leakage from the Be region, total power and power fraction per cell were examined. Nuclear densities in the mixed-flow gas reactor are given in Appendix A. B. Four-Cell Radial Reactor.

The 4-cell radial consists of fuel cells embedded in a circular cylinder of Be. One fuel is located in the center of the be matrix and the remaining 3 fuel cells have $3 / 2 \pi$ angular symmetry.

1. Calculational Results. A summary of the results for the 4-cell radial reactor is given in Table $I$. The CC and CP columns indicate the fuel charge in the central and peripheral fuel. cells, respectlvely. Various leakage columns indicate the fractional neutron leakage. For the reactor to breed, at least $48-50 \%$ of the neutrons must leak out of the system. Total power is the fractional power from a single neutron. Cells 1 and 4 are the central hot-fuel region for the center and perlpheral fuel cells; cells 2 and 3 are the buffer regions for the center and peripheral cells, respectively.

From Table I several conclusions can be drawn, the most important of which is that a 4-cell $\mathrm{U}$-233-or U-235-loaded reactor is not viable. If W1, W2, and $T$ are adjusted co yield a critical system, there is not sufficient leakage for breeding. This is because of the excess amounts of Be between peripheral cells which capture the thermal neutrons. Also, the central cell (cell 1) power is severely peaked which would cause operational problems. The power can be flattened by reducing the amount of charge in the central region as seen in case 12; however, the system does not have sufficlent neutron leakage for breeding. Additional $4-c e l l$ analysis results are given in Appendix $B$. 
2. Conclustons. Although there were several $\mathrm{W} 1, \mathrm{~W} 2$, and $\mathrm{T}$ parameter studies, the 4-cell reactor concept was abandoned since It could not satisfy all design criteria. The reactor contains an excessive amount of Be; although this Be does moderate, there is too much parasitic neutron capture, thereby reducing the required neutron leakage into the thorium molten salt blanket. Beryllium is used very inefficiently.

\section{Seven-Cell Radiai Reactor}

The only difference between the 4-cell and 7 -cell radial reactors is that

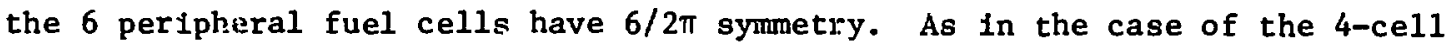
reactor, the effect of $W 1$, $W 2$, and $T$ on $k_{\text {eff }}$, total leakage from the Be region, total power, and power fraction per cell were examined.

1. Calculational Results. A summary of the results for the 7 -cell radial reactor is given in Table II. This table is simflar to Table I with the addition of power fraction caused by epithermel fissioning. The numbers in paintheses represent that fraction of the power in a particular cell as a result of epithermal f\&ssion.

The U-235 radial reactor cannot attain criticality and a conversion ratio greater than unity simultaneously. This is not a serious problem at the beginning of core life since the U-235 reactor produces enough U-233 feed that it quickly bec umes a U-2.33 reactor.

Cas o demonstrates that a U-233 reactor is critical with marginal breeding potential. Because the gas entrance and exit pipes and the plenum preclude an "equivalent" Be thickness much greater than $10-15 \mathrm{~cm}$, there was no reason to examine additional thicknesses. With respect to the W2 values, going below 13-15 cm would exceed reasonable crttical masses and above $20 \mathrm{~cm}$ would drop the freeding ratio below acceptable values.

2. Concluston. Because of the excessive amounts of Be between cells near the peripheral walls, more thermal neutrons tend to be captured in the Be. From the standpoint of flexibility in operation and economics (high cost of $\mathrm{Be}$ ), the radial reactor is not the most optimized configuration for the mixed-flow gascore reactor.

D. Seven-Cel1 Scallop Reactor

The 7-cell scallop reactor consists of 7 circular cylinders, 1 in the center and 6 wtth $6 / 2 \pi$ symmetry embedied in a beryllium matrix whose radial surface is scalloped to maintatn a constant thickness between the six peripheral cells and the "black" outer boundary of the beryllium. A 7-cell scallop 
TABLE I

4-CELL U-233-LOADED RADIAI, REACTOR

\begin{tabular}{|c|c|c|c|c|c|c|c|c|c|c|c|c|c|c|}
\hline \multirow[b]{2}{*}{ Caoe } & \multirow[b]{2}{*}{$\underline{c c^{\mathrm{a}}}$} & \multirow[b]{2}{*}{$\mathrm{CP}^{\mathrm{a}}$} & \multirow{2}{*}{$\begin{array}{l}\mathrm{N1} \\
(\mathrm{cm})\end{array}$} & \multirow{2}{*}{$\begin{array}{l}\mathrm{H} / 2 \\
(\mathrm{~cm})\end{array}$} & \multirow{2}{*}{$\begin{array}{c}T \\
(\mathrm{~cm})\end{array}$} & \multirow[b]{2}{*}{$\underline{\text { eff }}$} & \multirow{2}{*}{$\begin{array}{l}\text { Radial } \\
\text { Leakage }\end{array}$} & \multirow{2}{*}{$\begin{array}{l}\text { Top/Bot } \\
\text { Leakage }\end{array}$} & \multirow{2}{*}{$\begin{array}{c}\text { Total } \\
\text { Leakage }\end{array}$} & \multirow{2}{*}{$\begin{array}{l}\text { Tntal } \\
\text { Power } \\
\end{array}$} & \multicolumn{4}{|c|}{ Power Braction/Cell } \\
\hline & & & & & & & & & & & Cel11 & Cel12 & Cel13 & Ce114 \\
\hline 1 & 1.0 & 1.0 & 25 & 24 & 45 & 1.163 & - & -5 & - & 0.476 & 17.4 & 18.6 & 5.5 & 5.1 \\
\hline 2 & 0.5 & 0.5 & 25 & 24 & 45 & 0.978 & - & $\rightarrow$ & - & 0.397 & 18.2 & 19.3 & 5.4 & 5.1 \\
\hline 3 & 0.5 & 0.5 & 35 & 34 & 35 & 0.924 & 0.107 & $\cdots$ & $0.504^{b}$ & 0.389 & 17.3 & 18.3 & 5.5 & 5.3 \\
\hline 4 & 0.5 & 0.5 & 25 & 24 & 35 & 0.930 & 0.152 & - & $0.454^{b}$ & 0.394 & 18.8 & 19.6 & 5.2 & 5.3 \\
\hline 5 & 0.5 & 0.5 & 15 & 14 & 15 & 0.839 & 0.228 & 0.150 & 0.378 & 0.349 & 16.6 & 17.8 & 5.3 & 5.3 \\
\hline 6 & 1.0 & 1.0 & 15 & 15 & 15 & 1.068 & 0.194 & 0.118 & 0.312 & 0.448 & 17.4 & 17.8 & 5.5 & 5.3 \\
\hline 7 & 1.0 & 1.0 & 12 & 18 & 15 & 1.09 & 0.175 & 0.125 & 0.300 & 0.460 & 15.2 & 16.3 & 5.8 & 5.4 \\
\hline 8 & 2.0 & 1.0 & 6 & 15 & 15 & 1.029 & 0.212 & 0.120 & 0.332 & 0,431 & 14.6 & 15.5 & 6.0 & 5.7 \\
\hline 9 & 1.0 & 1.0 & 6 & 20 & 15 & 1.118 & 0.172 & 0.115 & 0.287 & 0.461 & 14.2 & 14.4 & 6.1 & 5.8 \\
\hline 10 & 1.0 & 1.0 & 6 & 20 & 20 & 1.123 & 0.175 & 0,100 & 0.275 & 0,465 & 14.4 & 15.2 & 6.0 & 5.7 \\
\hline 11 & 1.0 & 0.5 & 6 & 20 & 20 & 0.988 & 0.189 & 0.143 & 0.332 & 0.412 & 20.0 & 21.2 & 5.0 & 4.8 \\
\hline 12 & 0.5 & 1.0 & 6 & 20 & 20 & 1.030 & 0.189 & 0.127 & 0,316 & 0.438 & 10.4 & 10.7 & 6.7 & 6.4 \\
\hline
\end{tabular}

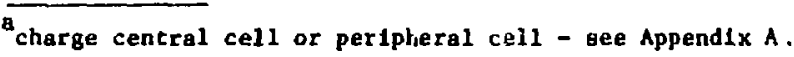

$b_{\text {total leakage + capture. }}$

TABLE II

7-CELL, RADLAL REACTOR

\begin{tabular}{|c|c|c|c|c|c|c|c|c|c|c|c|c|c|c|c|}
\hline \multirow[b]{2}{*}{ Case } & \multirow[b]{2}{*}{ Load } & \multirow[b]{2}{*}{$c c^{a}$} & \multirow[b]{2}{*}{$\underline{\mathrm{CP}^{\mathrm{a}}}$} & \multirow{2}{*}{$\begin{array}{c}W 1 \\
(\mathrm{~cm})\end{array}$} & \multirow{2}{*}{$\begin{array}{l}\text { W2 } \\
(\mathrm{cm})\end{array}$} & \multirow{2}{*}{$\begin{array}{c}T \\
(\mathrm{~cm})\end{array}$} & \multirow[b]{2}{*}{ keff } & \multirow{2}{*}{$\begin{array}{l}\text { Rad. } \\
\text { Leak } \\
\end{array}$} & \multirow{2}{*}{$\begin{array}{l}T / B^{b} \\
\text { Leak } \\
\end{array}$} & \multirow{2}{*}{$\begin{array}{l}\text { Total } \\
\text { Leak } \\
\end{array}$} & \multirow{2}{*}{$\begin{array}{l}\text { Total } \\
\text { Power }\end{array}$} & \multicolumn{4}{|c|}{$\begin{array}{l}\text { Fraction power/cell } \\
\text { (power }>\text { leV flaolon) }\end{array}$} \\
\hline & & & & & & & & & & & & Cell1 & Cel112 & CeI13 & Ce114 \\
\hline 1 & $u-235$ & 1.0 & 1.0 & 15 & 15 & 15 & 1.188 & - & - & 0.341 & 0.497 & 9.2 & 9.5 & 6.9 & 6.6 \\
\hline 2 & U-235 & 1.0 & 1.0 & 6 & 15 & 15 & 1.149 & 0.254 & 0.123 & 0.377 & 0.475 & 7.5 & 8.1 & 7.3 & 6.8 \\
\hline 3 & $U-233$ & 1.0 & 1.0 & 6 & 15 & 15 & 1.338 & 0.243 & 0.119 & 0.362 & 0.532 & 7.5 & 8.1 & 7.2 & 6,8 \\
\hline 4 & U-235 & 0.5 & 1.0 & 6 & 20 & 15 & 1.177 & 0.221 & 0.129 & 0.350 & 0.491 & 4.8 & 5.1 & 7.6 & 7.3 \\
\hline 5 & U-235 & 0.5 & 0.5 & 6 & 15 & 15 & 0.955 & 0.312 & .149 & 0.461 & 0.394 & $\begin{array}{l}7.5 \\
(5.2)\end{array}$ & $\begin{array}{c}8.0 \\
(5.2)\end{array}$ & $\begin{array}{l}1.2 \\
(4.8)\end{array}$ & $\begin{array}{c}6.9 \\
(4.7)\end{array}$ \\
\hline 6 & U-233 & 0.5 & 0.5 & 6 & 15 & 15 & 1.119 & 0.292 & 0.141 & 0.433 & 0.444 & $\begin{array}{r}8.2 \\
(12.3)\end{array}$ & $\begin{array}{c}8.6 \\
(12.6)\end{array}$ & $\begin{array}{c}7.1 \\
(10.9)\end{array}$ & $\begin{array}{c}6.8 \\
(9.8)\end{array}$ \\
\hline
\end{tabular}

"charge central cell or peripheral cell - see Appendix A.

bop and buttom leakage. 
reactor is illustrated in F1g. 1. Both the top and bottom Be surfaces are flat but have the same peripheral scallop shape as the core Be matr:x;

1. Calculational Results. A summary of the 7-cell scallop reactor is given in Table III. For most U-233 loadings the reactors are critical, can breed, and have good power distribution. On the other hand most U-235-locided reactors are critical, have good power distributions, but do not have a conversion ratio larger than unity. As in the case of the 7 -cell radial reactor, this is not a problem since the initially loaded U-235 will quickly become a U-233 reactor even with a conversion ratio near 0.8 . See Section $\mathrm{E}$ and Appendix $\mathrm{C}$ for detailed discussion.

2. Conclusion. Because of better Be utilization the scallop reactor satisfies a.l design criterla of criticality, breeding, and power distribution. Although the U-235 loaded core cannot initlally breed, the economics are attractive to start with this system and let it become a U-233 system. E. Discussion of Seven-Ce11 Reactors

For flxed $W 1, W 2$, and $T$, the scallop reactor uses less $B e$ and has a higher breeding ratio than the radial reactor. Using either U-235 of U-233 loaded radial or scallop cores, the clean critical mass as a function of Be mass, the breeding ratio as a function of Be mass, and the central/outer power ratio as a function of fuel gas densities have been determined.

Figure 1 shows the radial cross section of the scallop mixed-flow reactor configuration. The fuel cavities are $1 \mathrm{~m}$ in diameter and $4.35 \mathrm{~m}$ in length. With the fuel loadings discussed in Appendix A the power rating of the reactor is $200 \mathrm{MWth}$. The beryllium web between the central cavity and the outer cells (W1) Is $6 \mathrm{~cm}$ as are the webs between adjacent fuel cells. The web between the outer cavities and the "black" outer boundary of the beryllium is $15 \mathrm{~cm}$. Using a top and botiom thickness of $15 \mathrm{~cm}$ on the reactor, the total beryllfum weighs about 24 metric tons: For a radial reactor with identical W1, W2, and $T$ specifications the Be requirements are $60 \%$ higher and the breeding ratio $20 \%$ lower.

Figure 2 shows both the U-233 and U-235 converstion ratios as a function of the Be mass (see Appendiyes $C$ and $D$ for detail and discussion). A U-235 breeding ratio greater than unity cannot be achelved. With a near optimum configuration a breeding ratio of 0.8 can be achieved. Fallure to achieve a breeding ratio of unity with $\mathrm{U}-235$ does not mean that this reactor cannot start 
TABLE 11.

7-CEJ,L SCALLOR REACTOR

\begin{tabular}{|c|c|c|c|c|c|c|c|c|c|c|c|c|c|c|c|}
\hline \multirow[b]{2}{*}{ Casee } & \multirow[b]{2}{*}{ Load } & \multirow[b]{2}{*}{$\underline{c c^{8}}$} & \multirow[b]{2}{*}{$\underline{\mathrm{CP}^{2}}$} & \multirow{2}{*}{$\begin{array}{l}\text { W1 } \\
(\mathrm{cm})\end{array}$} & \multirow{2}{*}{$\begin{array}{l}\mathrm{H} 2 \\
(\mathrm{~cm})\end{array}$} & \multirow{2}{*}{$\stackrel{I}{s(0)}$} & \multirow[b]{2}{*}{ keff } & \multirow{2}{*}{$\begin{array}{l}\text { Rad. } \\
\text { Lcak } \\
\end{array}$} & \multirow{2}{*}{$\begin{array}{l}T / B^{b} \\
\text { Leak } \\
\end{array}$} & \multirow{2}{*}{$\begin{array}{l}\text { Total } \\
\text { leak } \\
\end{array}$} & \multirow{2}{*}{$\begin{array}{l}\text { Total } \\
\text { Power }\end{array}$} & \multicolumn{3}{|c|}{$\begin{array}{l}\text { Fraction pover/ceil } \\
\text { (power }>\text { lev (1seion) }\end{array}$} & \multirow[b]{2}{*}{ Ced14 } \\
\hline & & & & & & & & & & & & C.111 & Cel12 & Ce.113 & \\
\hline 1 & $u-233$ & 1.0 & 1.0 & 6 & 13 & 10 & 0.958 & 0.441 & 0.150 & 0.591 & 0.395 & 8.8 & 9.3 & 7.0 & 6.6 \\
\hline 2 & $u-23 j$ & 2.0 & 2.0 & 6 & 13 & 10 & 1.162 & 0.382 & 0.131 & .531 & 0.436 & 8.8 & 9.7 & 7.1 & 6.5 \\
\hline 3 & $\begin{array}{l}U-233 \\
\text { B-10 polson } \\
\text { (1/100 rf U-233) }\end{array}$ & 2.0 & 2.0 & 6 & 13 & 10 & 1.110 & 0.384 & 0.126 & 0.513 & 0.455 & 9.0 & 9.7 & 7.1 & 6.4 \\
\hline 4 & $v-233$ & 1.0 & 2.5 & 6 & 13 & 10 & 1.071 & 0.415 & 0.139 & 0.554 & 0.436 & 7.5 & 8.0 & 7.2 & 6.8 \\
\hline 5 & $v-233$ & 1.0 & 1.5 & 6 & 13 & 10 & 1.014 & 0.443 & 0.149 & 0.592 & 0.412 & 7.2 & 7.7 & 7.3 & 6.9 \\
\hline 6 & $U-233$ & 1.0 & 1.0 & 6 & 15 & 10 & 1.052 & 0.383 & 0.155 & 0.538 & 0.427 & $\begin{array}{r}8.4 \\
(21.6)\end{array}$ & $\begin{array}{c}9.1 \\
(21.0)\end{array}$ & $\begin{array}{c}7.1 \\
(19.6)\end{array}$ & $\begin{array}{c}6.7 \\
(19.3)\end{array}$ \\
\hline 7 & $v-233$ & 1.0 & 1.0 & 6 & 20 & 10 & 1.179 & 0.311 & 0.149 & 0.460 & 0.469 & $\begin{array}{c}7.2 \\
(19.9)\end{array}$ & $\begin{array}{r}7.6 \\
(20.0)\end{array}$ & $\begin{array}{c}7.3 \\
(17.1)\end{array}$ & $\begin{array}{c}6.9 \\
(17.0)\end{array}$ \\
\hline 8 & $v-233$ & 0.5 & 0.5 & 6 & 20 & 10 & 0.952 & 0.373 & 0.183 & 0.556 & 0.383 & $\begin{array}{c}7.8 \\
(13.5)\end{array}$ & $\begin{array}{c}7.8 \\
(13.6)\end{array}$ & $\begin{array}{c}7.1 \\
(12.4)\end{array}$ & $\begin{array}{c}6.9 \\
(12.3)\end{array}$ \\
\hline 9 & $v-233$ & 0.5 & 0.5 & 6 & 25 & 10 & 0.997 & 0.302 & 0.194 & 0.496 & 0.423 & $\begin{array}{c}7.9 \\
(12.3)\end{array}$ & $\begin{array}{c}8.2 \\
(13.1)\end{array}$ & $\begin{array}{c}7.1 \\
(11.5)\end{array}$ & $\begin{array}{c}6.9 \\
(11.4)\end{array}$ \\
\hline 10 & $U-233$ & 0.5 & 0.5 & 6 & 25 & 15 & 1.111 & 0.306 & 0.136 & 0.442 & 0.441 & $\begin{array}{c}7.4 \\
(11.8)\end{array}$ & $\begin{array}{c}7.8 \\
(13.4)\end{array}$ & $\begin{array}{c}7.2 \\
(10.4)\end{array}$ & $\begin{array}{c}6.9 \\
(10.3)\end{array}$ \\
\hline 11 & $0-235$ & 1.0 & 1.0 & 6 & 13 & 20 & 0.825 & 0.454 & 0.154 & 0.608 & 0.348 & 8.9 & 9.2 & 7.0 & 6.6 \\
\hline 12 & $U-235$ & 2.0 & 2.0 & 6 & 13 & 10 & 0.928 & 0.407 & 0.139 & 0.545 & 0.384 & 9.2 & 9.9 & 7.0 & 6.4 \\
\hline 13 & $u-235$ & 5.0 & 5.0 & 6 & 13 & 10 & 1,076 & 0.350 & 0.119 & 0,469 & 0.441 & 8.6 & 10.3 & 7.4 & 6.2 \\
\hline 14 & $\mathrm{Jj}-235$ & 1.0 & 1.0 & 6 & 15 & 10 & 0.891 & 0.412 & 0.157 & 0.569 & 0.369 & $\begin{array}{l}8.5 \\
(9.8)\end{array}$ & $\begin{array}{c}8.9 \\
(10.1)\end{array}$ & $\begin{array}{l}7.1 \\
(9.1)\end{array}$ & $\begin{array}{c}6.7 \\
(9.0)\end{array}$ \\
\hline 15 & $U-235$ & 2.0 & 1.0 & 6 & 15 & 10 & 1.048 & 0.358 & 0.132 & 0.490 & 0.425 & $\begin{array}{c}8.0 \\
(14.6)\end{array}$ & $\begin{array}{c}8.6 \\
(14.7)\end{array}$ & $(14.1)$ & $\begin{array}{c}6.7 \\
(14.8)\end{array}$ \\
\hline 16 & $U-235$ & 1.0 & 1.0 & 6 & 20 & 10 & 1.013 & 0.315 & 0.166 & 0.481 & 0.421 & $\begin{array}{l}7.8 \\
(9.3)\end{array}$ & $\begin{array}{c}8.0 \\
(9.1)\end{array}$ & $\begin{array}{c}7.3 \\
(8.3)\end{array}$ & $\begin{array}{c}6.8 \\
(8.5)\end{array}$ \\
\hline 17 & $U-235$ & 2.0 & 2.0 & 6 & 20 & 10 & 1.1430 & 0.277 & 0.146 & 0.423 & 0.473 & $\begin{array}{l}7.6 \\
(14.6)\end{array}$ & $\begin{array}{c}8.3 \\
(14.6)\end{array}$ & $\begin{array}{c}7.3 \\
(12.6)\end{array}$ & $\begin{array}{c}6.8 \\
(12.6)\end{array}$ \\
\hline 18 & $v-235$ & 1.0 & 1.0 & 6 & 20 & 15 & 1.068 & 0.334 & 0.120 & 0.454 & 0.437 & $\begin{array}{c}8.3 \\
(8.2)\end{array}$ & $\begin{array}{c}8.6 \\
(8.5)\end{array}$ & $(7.7)$ & $\begin{array}{c}6.7 \\
(7.6)\end{array}$ \\
\hline 19 & $U-235$ & 0.5 & 0.5 & 6 & 25 & 15 & 0.883 & 0.313 & 0.210 & 0.523 & 0.370 & $\begin{array}{l}8.1 \\
(5.8)\end{array}$ & $\begin{array}{c}8.3 \\
(5.5)\end{array}$ & $\begin{array}{c}7.1 \\
(4.8)\end{array}$ & $\begin{array}{c}6.8 \\
(4.9)\end{array}$ \\
\hline 20 & $U-235$ & 1.0 & 1.0 & 6 & 25 & 15 & 1.067 & 0.253 & 0.163 & 0.416 & 0.433 & $\begin{array}{l}7.4 \\
(9.7)\end{array}$ & $\begin{array}{l}7.8 \\
(9.5)\end{array}$ & $\begin{array}{l}7.3 \\
(7.4)\end{array}$ & $\begin{array}{c}6.9 \\
(7.4)\end{array}$ \\
\hline 21 & $1-235$ & 1.0 & 1.0 & 10 & 20 & 15 & 1.110 & $c, 308$ & 0.113 & 0.421 & 0.452 & $\begin{array}{c}9.3 \\
(6.9)\end{array}$ & $\begin{array}{c}9.6 \\
(6.8)\end{array}$ & $\begin{array}{l}7.0 \\
(6.5)\end{array}$ & $\begin{array}{c}6.5 \\
(6.6)\end{array}$ \\
\hline
\end{tabular}


without U-233. Since the product is $\mathrm{U}-233$, the reactor could be started on U-235 and $1 t$ would simply cake longer to generate a critical mass of U-233. Figure 3 shows both the U-233 and U-235 critical masses as a function of beryllium mass (see Appendixes $C$ and $D$ for detail. discussion). From Fig. 2 the U-233 breeding ratio of unity corresponds to a Be mass of about 24 metric tons. Fig. 3 shows that for 24 metric tons of Be the U-233 critical mass is about $45 \mathrm{~kg}$ and that of U-235 is about $70 \mathrm{~kg}$.

W1th $45 \mathrm{~kg}$ of $\mathrm{J}-233$ in the fuel cavity and an additional $45+\mathrm{kg}$ in the remaining parts of the reactor system, the resulting $90+\mathrm{kg}$ of fissile materlal is still small. This is an order of magnitude less than the fissile inventory of current reactors of comparable power.

Figure 4 depicts the power ratio of the central to outer cell as a function of W2 for a fixed W1. Based on Be economics and other operating parameters a W1 larger than $6 \mathrm{~cm}$ is not, practical; however, one point is given for $W 1$ in the 10 to $15 \mathrm{~cm}$ range. From Fig. 4 it is clear that as W2 Increases that power distribution is flatter, but clearly the breeding potential suffers. These power distributions are similar for both the scallop and radial reactors.

\section{CONCLUSIONS}

The neutronic analysis of the mixed-flow gas-core reactor has led us to conclude that it is a very attractive reactor concept. Using a 7-cell scallop reactor configuration $1 t$ is possible to obtain small critical masses, a breeding ratio larger than unity, and flat power distributions. Based on this analysis the fissile inventory is a factor of 10 less than that of a comparable conventional reactor. This feature reduces the possibility of surreptitious diversion of fissile material.

No kinetic analysis has been performed on the mixed-flow gas-core concept. There is a need to understand the power stability and associated control problems for the mixed-flow gas-core reactor.

\section{ACKNOWLEDGMENTS}

Special thanks to Ed Cashwell and Tom Hirons for several discussions on Monte Carlo setup and transport. 

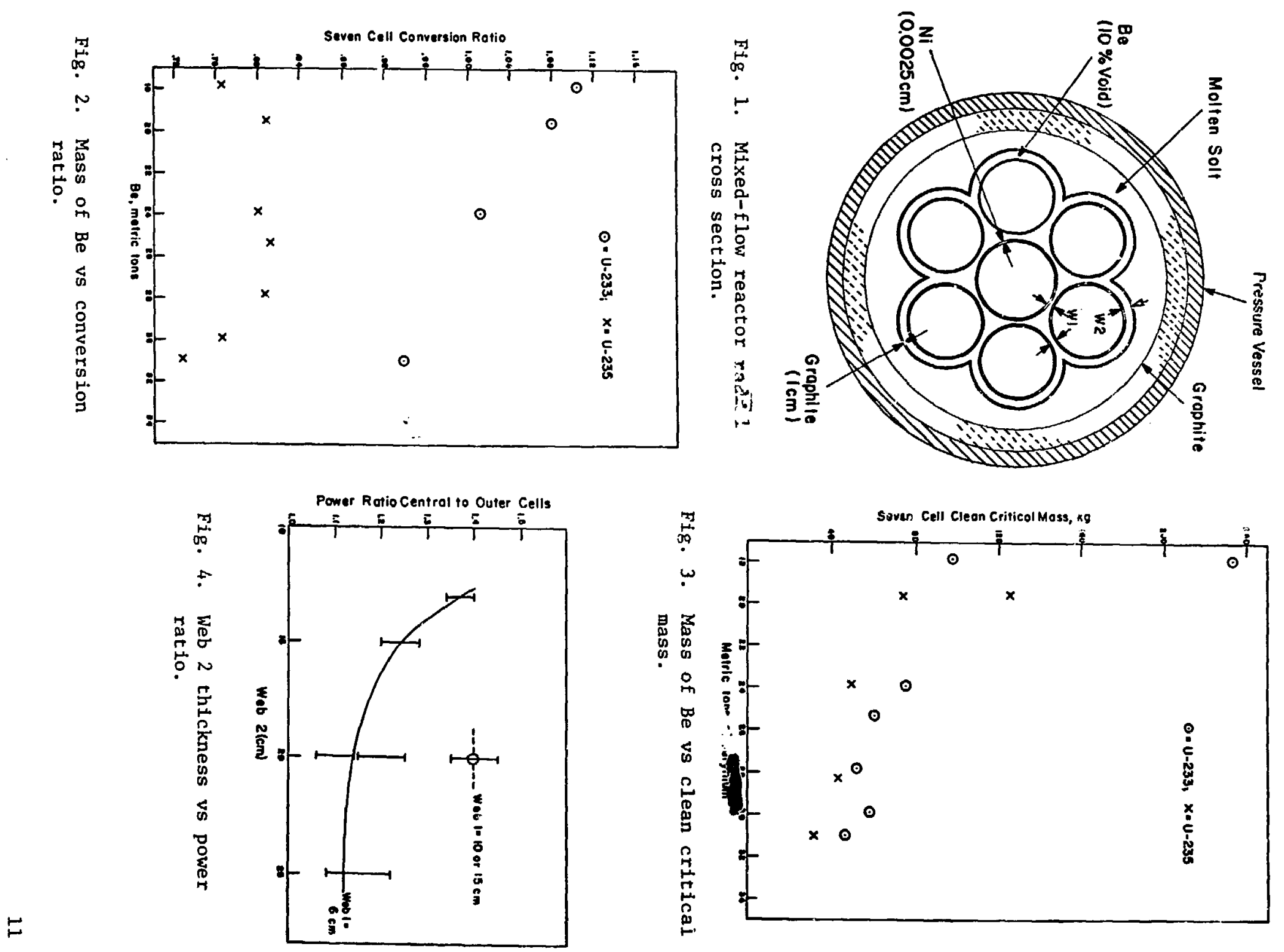


\section{REFERENCES}

1. Luther L. Lowry, "Gas Core Reactor Power Plant Designed ior Low ProIiferatior, Potent1al," Los Alamos Scient1tic Laboratory report LA-6900-MS (Sept. 1977).

2. L. L. Carter, "Monte Carlo Code Development in Los Alamos," Los Alanios Scientific Laboratory report LA-5903-MS (1975).

3. Patrick D. Soran, "Los Alamos Monte Carlo Cross Sections," unpublished data (1976).

\section{APPENDIX A}

NUCLEAR DFNSITIES IN MIXED-FLOW GAS REACTOR

Based upon a cavity pressure of 100 atomsphere, a cavity residence time of 3 seconds, and a total mass flow rate $63 \mathrm{~kg} / \mathrm{s}$, the thermal rating of the reactor is $200 \mathrm{MWth}$. To increase the plant size to $2500 \mathrm{MWth}$ the dimensions and configuration of the cavities require no changes; however, the cavity pressure, residence, and flow rate would have to be changed to $650 \mathrm{~atm}, 1.5 \mathrm{~s}$, and 625 $\mathrm{kg} / 2$, respectively.

For a 200-MWth system the following nuclear densities are used and referenced in the report as $1.0(p \equiv 1.0)$ :

Central Region:

$\begin{array}{cccccc} & \text { He } & \text { F } & \text { U-235 } & \text { U-238 } & \text { UF } 6 \\ \rho & 4.82-3 & 1.534-3 & 2.949-3 & 0.2169-3 & 4.70-3 \\ \text { N } & 7.211-4 & 4.863-5 & 7.557-6 & 5.488-7 & 7.778-4\end{array}$

Buffer Region:

$\begin{array}{llllll}\rho & 6.43-3 & 2.043-3 & 3.928-3 & 0.289-3 & 6.26-3 \\ N & 9.619-4 & 6.477-5 & 1.007-5 & 7.310-7 & 1.037-3\end{array}$




\section{AFPSNDIX B}

FOUR-CELL MIXED-FLOW GAS-CORE ANALYSIS

In conjunction with Table I the following additional information is given:

$\begin{array}{cl}\text { Case } & \text { Power Ratio (Central/Peripheral Ce11s) } \\ 1 & 1.74 \pm 0.04 \\ 6 & 1.62 \pm 0.05 \\ 7 & 1.41 \pm 0.07 \\ 8 & 1.29 \pm 0.07 \\ 9 & 1.20 \pm 0.07 \\ 10 & 1.26 \pm 0.07\end{array}$

Dependence on gas density ratios $\rho_{1} / \rho_{2}$ where $\rho_{1}=$ central cell density. Assume that

$$
R=R_{0}\left(\rho_{1} / \rho_{2}\right)^{n}
$$

For case 10 then

case $11 \quad \begin{aligned} & 2.10=1.26(2)^{\mathrm{n}} \quad \mathrm{n}=0.74 \\ & 0.81=1.26(1 / 2)^{\mathrm{n}} \mathrm{n}=0.64 .\end{aligned}$

\section{APPENDIX C}

SEVEN-CELL MIXED-FLOW GAS-CORE ANALYSIS

This appendix gives the central-to-peripheral cell power ratio and the power ratio as a function of gas density. Furthermore, the explicit data for the generation of Figures 1 and 2 are given in this appendix.

In conjunction with Table III the following power ratios are given for the seven-cell scallop reactor and were used to produce Fig. 4: 


\section{Power Ratios}

Case

1

6

8

9

18

21
Central/Peripheral Cells

$1.37 \pm 0.03$

$1.24 \pm 0.04$

$1.10 \pm 0.04$

$1.15 \pm 0.07$

$1.20 \pm 0.05$

$1.40 \pm 0.07$

The dependence on gas density ratios, $\rho_{1} / \rho_{2}$, where $\rho_{1}=$ central cell density is given by

$$
R=R_{0}\left(\rho_{1} / \rho_{2}\right)^{n}
$$

Using case 2 of Table III

$$
1.11=1.33(2 / 3)^{n}
$$

solving for $n$ yields 0.31 .

Using the interpolation algorithm results of Appendix D, Table III, and the following assumptions

1) $5 \% \Delta \mathrm{k} / \mathrm{k}$ poison due to insertion of nickel liners for the gas cells, and

2) $90 \%$ of leakage neutrons are captured in the thorium, the conversion and breeding ratio, illustrated in Fig. 2, are calculated for both the U-233 and U-235 loadings. the breeding and conversion ratio interpolation constants $\left(\mathrm{L} / \mathrm{A}_{\mathrm{g}}\right.$ ) are obtaind from Appendix $\mathrm{D}$ and upon multiplying by 0.9 the B.R. and C.R. values are obt ined.

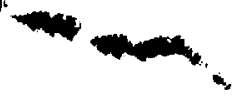


Case Materlal Breed. Ratio(B.R) Conv. Ratic(C.R.) Fuel Mass(kg) Be(tons)

$\begin{array}{llccrr}1,2 & \mathrm{U}-233 & 1.104 & -- & 114 & 17.8 \\ 11,12 & \mathrm{U}-235 & --- & 0.765 & 323 & 17.8 \\ 6 & \mathrm{U}-23: & 1.08 & --- & 85 & 19.6 \\ 14,15 & \mathrm{U}-235 & --- & 0.807 & 163 & 19.6 \\ 7,8 & \mathrm{U}-233 & 1.012 & -- & 56 & 23.9 \\ 16,17 & \mathrm{U}-235 & --- & 0.80 & 94 & 23.9 \\ 18,19 & \mathrm{U}-235 & --- & 0.812 & 74 & 25.3 \\ 10 & \mathrm{U}-235 & -- & 0.763 & 69 & 29.9 \\ 3,6 & \mathrm{U}-233 * & 0.938 & -- & 36 & -2 \\ 2,5 & \mathrm{U}-235 * & -- & 0.726 & 55 & 31.0\end{array}$

*radial - Table II

A unit charge $(\rho=1.0)$ of $U-233$ corresponds to $85.5 \mathrm{~kg}$ and of $\mathrm{U}-235$ corresponds to $79.8 \mathrm{~kg}$. Using the critical gas densities given in Appendix D and the unit charge, the clean critical mass as a function of Be mass can be determined as shown in Fig. 3.

Clean Critical Mass vs Be Mass

\begin{tabular}{lccrl}
\multicolumn{1}{c}{ Case } & Material & Be Mass(tons) & \multicolumn{2}{c}{ Critical Mass (kg) } \\
\cline { 1 - 3 } 1,2 & U-233 & 17.82 & 97.0 & $(1.135) *$ \\
11,12 & $\mathrm{U}-235$ & 17.82 & 233.0 & $(2.92)$ \\
6 & $\mathrm{U}-233$ & 19.55 & 73.1 & $(0.855)$ \\
14,15 & $\mathrm{U}-235$ & 19.55 & 126.3 & $(1.583)$ \\
7,8 & $\mathrm{U}-233$ & 23.88 & 48.8 & $(0.571)$ \\
16,17 & $\mathrm{U}-235$ & 23.88 & 75.5 & $(0.946)$ \\
19 & $\mathrm{U}-233$ & 28.39 & 42.8 & $(0.5)$ \\
18,19 & $\mathrm{U}-235$ & 25.29 & 60.2 & $(0.755)$ \\
10 & $\mathrm{U}-235$ & 29.89 & 58.8 & $(0.737)$ \\
Other Data & $\mathrm{U}-235$ & 27.82 & 51.6 & $(0.646)$ \\
3,6 & $\mathrm{U}-233 * *$ & 31.02 & 25.7 & $(0.30)$ \\
2,5 & $\mathrm{U}-235 * *$ & 31.02 & 36.7 & $(0.46)$
\end{tabular}

* (charge fraction)

**radial 


\section{APPENDIX D}

\section{INTERPOLATION ALGORITHM AND RESULTS}

This appendix discusses the method in which fuel charges are interpolated or extrapolated for purposes of fuel loadings. The ratio of leakage to gas absorption is also discussed.

\section{D.I. Criticality Problem}

For a fixed beryllium geometry it is necessary to determine the critical density of $\mathrm{UF}_{6}$ gas as a function of :

1) Isotopic composition of uranium, and

2) neutron losses in linings between gas cavities and beryllium.

The data which are avallable from a set of Monte Carlo calculations are:

$k_{1}$ - eigenvalue of the 1 -th system

$m_{1}$ - neutrons per source neutron (1.e., multiplication by $n, 2 n$ in Be) for 1 -th system

$F_{1}$ - fissions per source neutron in 1 -th system

$\mathrm{L}_{1}$ - leakage per source neutron in 1 -th system

$F G_{1}$ - fraction of fissions caused by neutrons having energies above $1 \mathrm{eV}$.

For interpolation or extrapolation of the $\mathrm{UF}_{6}$ loading used in the Monte Carlo calculations, the following perturbation provides guidance:

$$
1-\frac{k}{k_{1}}=-\frac{\left\langle\phi\left[\left(v \sigma_{f} \chi\right)-\left(v \sigma_{f} \chi\right)_{1}\right] \phi^{+}\right\rangle-k_{1}\left\langle\phi\left(\sigma_{a}-\sigma_{a 1}\right) \phi^{+}\right\rangle}{\left\langle\phi v \sigma_{f} \chi \phi^{+}\right\rangle} \quad \text { (eq. D.I.1) }
$$

where: $\phi=$ flux associated with systems whose macroscopic cross sections are $\sigma_{f}$ and $\sigma_{a}$ and whose eigenvalue is $k$,

$\phi^{+}=$neutron importance associated with system $\sigma_{f 1}, \sigma_{a i}$, $k_{i}$, and

$<>$ = integration over phase space.

\section{D.I.A. Stmplifications}

Simplifications of the perturbation equation D.I.1 for changes in $\mathrm{UF}_{6}$ density and isotopic composition can be made based on the qualitative features of the $\phi$ and $\phi^{+}$distributions. 


\section{D.I.A.1. The $\phi$ distribution}

Fissions and absorptions in the gas cells are principally caused by low-energy neutrons, 1.e., thernal and eptthermal neutrons. The density distribution of these reactions increases monotonically from the cell center to the cell boundary. The $\phi$ distribution is adequately characterized by two parameters $g$ and $p$, where $g$ is the ratlo of epithermal flux (per unit lethargy) to thermal flux, and $p$ is the peak-to-mean ratio of the fission density. The $g$ parameter depends primarily on the beryllium volume and $p$ depends primarily on the gas density (absorptivity). Specifically, with increase of beryllium volume, $g$ decreases but $p$ increases slightly; whereas with in increase of gas density, $p$ increases but $g$ increases slightly. D.I.A.2. The $\phi^{+}$distribution

The crucial parameter in the $\phi^{+}$distribution is the parameter $W_{1}$ which is the mean Importance of neutrons absorbed in the gas relative to the mean importance of fission neutrons born in the gas. Fission neutron importance spatial distribution increases monotonically from cell center to cell boundary. This is because a fission neutron born at the cell center has the largest mean radial outward velocity component as it leaves the gas cell and thus the smallest probability of returning to propagate the fission chain. The fission neutron importance distribution can be described by the parameter $\mathrm{p}^{+}$which is the peak-to-inean ratio of fission neutron importance. Spatial distribution of low-energy neutron importance is relatively flat.

\section{I.A.3. Phase Space Integration}

Neutron scattering can be neglected in the fuel gas. Consequently only the isotopic components of $\phi$ and $\phi^{+}$are required thus the integration need only be over neutron energy and gas volume.

\section{D.II. Perturbation Equation}

To first order in $\mathrm{p}-1$ and $\mathrm{p}^{+}-1$, and letting $\langle f\rangle$ represent $\phi-$ averaged value of $f$, the perturbation equation can be writter as:

$$
\frac{1-k_{i}}{k}=1-\frac{\left\langle\sigma_{f i}\right\rangle}{\left\langle\sigma_{f}\right\rangle} \frac{-k_{i} w_{i}}{\left\langle\sigma_{f}\right\rangle} \frac{\left[<\sigma_{a}\right\rangle-\left\langle\sigma_{a 1}\right]}{\left[1+\frac{1}{3}\left(p-p_{i}\right)\left(p^{+}-1\right)\right]} \text {. (eq. D.II.1) }
$$


It has also been assumed that

$$
\left(v \sigma_{f}\right)^{\text {th }}>g *\left(v \sigma_{f}\right)^{\text {res }} \text {, }
$$

and

$$
\left(\sigma_{a}\right)^{\text {th }} \gg g *\left(\sigma_{a}\right)^{\text {res }} \text {. }
$$

Thus $\mathrm{g}$ does not appear in the first-order expansion of the perturbation equat1on; however, 8 will be required in the calculation of breeding ratio in section D.IV.

$$
\text { Typically, }\left(p-p_{1}\right)<0.05 \text { and }\left(p^{+}-1\right)<0.1 \text { so that } 1 / 3\left(p-p_{1}\right)\left(p^{+}-1\right) \text { is }
$$

small compared to one. Introducing the parameter

$$
C_{i}=\frac{\left.w_{i}<\sigma_{a_{i}}\right\rangle}{\left\langle v \sigma_{f 1}\right\rangle}
$$

D.II.I can be written

$$
\frac{k_{i}}{k} \frac{e^{v \sigma_{f}}}{\left\langle v \sigma_{f>}\right.}\left\{1-c_{i} k_{i}\left[1-\frac{<\sigma_{a}}{\left\langle\sigma_{a 1>}\right.}\right]\right\} \text {. (eq. D.II. 2) }
$$

For gas changes $\left(\rho_{j}\right)$ eq. D.II. 2 can be written

$$
\frac{k_{1}}{k_{i}}=\frac{\rho_{i}}{\rho_{j}}\left\{1-c_{i} k_{i}\left[1-\frac{\rho_{1}}{\rho_{i}}\right]\right\}
$$

solvirg for $C_{i}$ yields

$$
c_{i}=\frac{\rho_{i}-\frac{k_{1}}{k_{j}} \rho_{j}}{k_{i}\left(\rho_{1}-\rho_{j}\right)}
$$

For the most part, the solution of eq. D.II.4 is the most important concern of this Appendix. 


\section{D.II.A. Parameter Specifications}

The geometry is that of the radial and scallop as discussed in sections

$C$ and D. Analysis in this appendix is for three relevant geometries:

$\begin{array}{cccc}\text { geometry no. } & \frac{\mathrm{W} 1(\mathrm{~cm})}{62} & \frac{\mathrm{W}(\mathrm{cm})}{\mathrm{T}(\mathrm{cm})} & \frac{10}{2} \\ 2 & 6 & 13 & 10 \\ 3 & 6 & 20 & 10\end{array}$

Because the Monte Carlo calculations assume a perfectly absorbing medium beyond the beryllium boundary, the $W 2$ and $i$ values correspond to "equivalent" Be thicknesses much greater than $10 \mathrm{~cm}$. For the chosen $W 2$ values, less than $13 \mathrm{~cm}$ would exceed reasonable gas inventory and greater than 20 would appreciably degrade the breeding ratios.

D.II.B. Nuclear Parameters

The following nuclear perameters are used in the analysis:

$\begin{array}{ccc}\text { Parameter } & \underline{\mathrm{U}-233} & \mathrm{U}-235 \\ \sigma_{\mathrm{f}}^{\text {th } *} & 2.47 & 2.43 \\ \sigma_{\gamma} & 268 & 290 \\ \sigma_{\mathrm{f}}^{\text {res * }} & 23.5 & 50 \\ \sigma_{\gamma}^{\text {res * }} & 850 & 274\end{array}$

*Units of barns. Thermal energy (Eth) is $0.0833 \mathrm{eV}$.

D.II.C. Reference Gas Density

The reference gas densities $(\rho \equiv 1)$ are those given in Appendix A.

D.III. Parameter Evaluations

The following data show an evaluation of $\mathrm{C}$ and $\mathrm{g}$ for geometry no. 1 . Detailed evaluation of $g$ is given in Table D.III.1. 


\begin{tabular}{|c|c|c|c|c|c|c|c|c|}
\hline Case $^{a}$ & Fuel & $\rho$ & $k$ & $\underline{L}-$ & $\mathbf{F}$ & $F(>1, V)=f$ & $g^{* *}$ & $\underline{F}$ \\
\hline 1 & $\mathrm{U}-233$ & 1.0 & 0.958 & 0.591 & 0.395 & $20 \%$ & $0.09 !$ & 1.02 \\
\hline 2 & $U-233$ & 2.0 & 1.162 & 0.513 & 0.463 & - & & 1.05 \\
\hline 3 & $u-233 *$ & 2.0 & 1.110 & 0.513 & 0.455 & - & & 1.03 \\
\hline 11 & $\mathrm{v}-235$ & 1.0 & 0.825 & 0.608 & 0.348 & - & & 1.01 \\
\hline 12 & $\mathrm{U}-235$ & 2.0 & 0.928 & 0.545 & 0.384 & $16 \%$ & 0.349 & 1.04 \\
\hline 13 & $\mathrm{U}-235$ & 5.0 & 1.076 & 0.469 & 0.441 & $28 \%$ & 0.811 & 1.15 \\
\hline
\end{tabular}

${ }^{\text {a }}$ see Table III.

* $\mathrm{B}-10$ added corresponding to $14 \mathrm{~b}$ per atom of $\mathrm{U}-233$. **see Table D.III.1 for calculation.

Inserting caser 1 and 2 into Eq. (D.II.4) yie]ds $\mathrm{C}(\mathrm{L}-233)=0.677 \pm 0.031$

Inserting cases 11 and 12 into Eq. (D.II.4) yields $\Gamma^{*} \mathrm{~T}-235$ ) $=0.943 \pm 0.036$

Inserting cases 12 and 13 into Eq. (D.II.4) yields $\mathrm{C}(U-235)=0.831 \pm 0.022$

Inserting cases 11 and 13 into Eq. (D.II.4) yields $C(U-235)=0.859 \pm 0.009$,

where the uncertainty in $C 18$ based on a $3 \%$ uncertainty in $k_{1} / k$. Averaging the above $C(U-235)$ yields 0.8 .

Similar analysis can be performed for geometries 2 and 3 with the results summarized for ail geometries in Table D.III.2.

Using the values of $C$ in Table D.III. 2 the densities for $k=1.0$ and $k=1.05$ can be calculated and are presented in Table D.III.3. These densities are used in Appendix $C$ to calculate the critfcal masses.

D.IV. Leakage and Gas Absorption

Calculating the ratio of leakage (L) to gas absorption (Ag) will yield the breeding ratio. Since the Monte Carlo resuits are not available at $k=1.0$, 1t is necessary to interpulate or extrapolate. To guide the interpolations or extrapolations of $\mathrm{L}$ and $\mathrm{Ag}$ the following equations are used

$$
\begin{aligned}
& m=1.10=A g+L+P \\
& A g=(1+\alpha) F \\
& F=k / v
\end{aligned}
$$

where $\alpha=$ radiative capture/fission in the gas, 


$$
\begin{aligned}
& \alpha=\frac{\sigma_{\gamma}^{\text {th }}}{\sigma_{f}^{\text {th }}}\left[1+\frac{\sigma_{\gamma}^{\text {res }}}{\sigma_{\gamma}^{\text {th }}} g\right] \int\left[1+\frac{f^{\text {res }}}{\sigma_{f}^{t l_{2}}} g\right] \\
& \mathrm{P}=\text { parasitic capture in the beryllium } \\
& k \text { = system eigenvalue }
\end{aligned}
$$

TABLE D.III.I

g-FACTOR EVALUATIONS

1. W1th $1 / v$ dependence: $\frac{F(0.4-1 \mathrm{eV})}{\mathrm{F}(0.4 \mathrm{eV})}=1.16 \mathrm{~g} \sqrt{E_{\mathrm{th}}}$.

$$
=0.335 \mathrm{~g}
$$

2. Fission fraction $>0.4 \mathrm{eV}$

$$
=0.335 \mathrm{~g}+[1+0.335 \mathrm{~g}] \frac{F(>l \mathrm{eV})}{1-F(>1 \mathrm{eV})} .
$$

\section{Geometry}

1

1

1

2

2

2

3

3

3

3

\section{Case $^{\mathrm{a}}$}

1

12

13

6

14

15

8

7

16

17
$F(>1 \mathrm{eV})$

0.20

0.16

0.28

0.20

0.095

0.146

0.13

0.185

0.0 ?

0.136

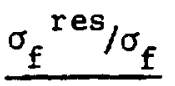

3.172

0.945

0.945

$3 . .272$

0.945

0.945

3.172

3.172

0.945

0.945

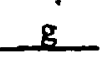

0.091

0.945

0.813

0.091

0.183

0.309

0.054

0.082

0.171

0.282

$a_{\text {see Table III. }}$ 
TABLE D.IIT. 2

EVALUATION OF C PARAMETER

\begin{tabular}{ccc} 
Geometry & $\frac{\text { Fue } 1}{\mathrm{U}}$ & $\mathrm{C}$ \\
\hline 1 & $\mathrm{U}-233$ & 0.68 \\
1 & $\mathrm{U}-235$ & 0.83 \\
2 & $\mathrm{U}-233$ & 0.66 \\
2 & $\mathrm{U}-235$ & 0.79 \\
3 & $\mathrm{U}-233$ & 0.65 \\
3 & $\mathrm{U}-235$ & 0.76
\end{tabular}

\begin{tabular}{cccc} 
& \multicolumn{3}{c}{ TABLE D.III.3 } \\
Geometry & Fuel & $\frac{\rho(k=1.00)}{}$ & $\frac{\rho(k=1.05)}{1.135}$ \\
1 & $U-233$ & 1.331 \\
1 & $U-235$ & 2.92 & 4.05 \\
2 & $U-233$ & 0.855 & 0.994 \\
2 & $U-235$ & 1.583 & 2.046 \\
3 & $U-233$ & 0.571 & 0.660 \\
3 & $U-235$ & 0.946 & 1.183 \\
$6,15,15$ radial & $U-233$ & 0.370 & 0.420 \\
$6,15,15$ radial & $U-235$ & 0.578 & 0.684
\end{tabular}

For all three geometries the value of $\mathrm{L}$ and $\mathrm{Ag}$ can be determined; however, only geometry 1 will be done in this Appendix and a table of results will be given for the remaining geometries. 
Geometry No. $1 \mathrm{U}-233$ fuel

$$
\text { Case 1: } \begin{aligned}
\alpha & =0.0877 *(1+4.255 * 0.091) /(1+3.172 * 0.091) \\
& =0.0944 \\
\mathrm{Ag} & =1.0944 * 0.395=0.432 \\
\mathrm{P} & =1.10-0.432-0.591=0.077 \\
\nu & =0.958 / 0.395=2.425 \\
\text { Case } 2: \quad \alpha & =0.0877 *(1+4.255 * 0.183) /(1+3.172 * 0.183) \\
& =0.0987 \\
\mathrm{Ag} & =1.0987 * 0.463=0.509 \\
\mathrm{P} & =1.10-0.509-0.513=0.078 \\
\nu & =1.362 / 0.463-2.51
\end{aligned}
$$

The correct value for $\nu$ is 2.47 and $P$ should decrease slightly in going from single to double density. Using the average values of the parameters

$$
\begin{aligned}
\mathrm{F} & =\mathrm{k} / 2.47 \\
\mathrm{Ag} & =1.096 \mathrm{~F} \\
\mathrm{Ag}+\mathrm{L} & =1.02 .
\end{aligned}
$$

The following table can be constructed

$\begin{array}{lllll}\frac{k}{1.00} & \frac{F}{0.405} & \frac{\mathrm{Ag}}{0.444} & \frac{\mathrm{L}}{0.576} & \frac{\mathrm{L} / \mathrm{Ag}}{1.297} \\ 1.05 & 0.425 & 0.466 & 0.554 & 1.189 \\ 1.10 & 0.445 & 0.489 & 0.531 & 1.086\end{array}$

A pure absorber $\delta \sigma_{a}$ can be added to the fuel cell to restore critfcallty, namely,

$$
\frac{1}{\mathrm{k}}=1-\frac{\mathrm{c} \delta \sigma_{\mathrm{a}}}{\sigma_{\mathrm{a}}+\delta \sigma_{\mathrm{a}}},
$$

for geometry 1 and $U-233 \quad C=0.68$

also

$$
\text { Agas }=(A+\delta A)\left(1-\frac{\delta \sigma a}{\sigma_{a}}\right)
$$


$\frac{k}{1.05} \quad \frac{\delta \sigma_{a} / \sigma_{a}}{0.070} \quad \frac{\delta \mathrm{A}}{0.0104} \quad \frac{\mathrm{Agas}}{0.443} \quad \frac{\mathrm{L}}{0.5436} \quad \frac{\mathrm{L} / \mathrm{Ag}}{1.227}$

so far poison in the system

poison (\%) $\quad \underline{\mathrm{L} / \mathrm{Ag}}$

$0 \quad 1.297$

$5 \quad 1.227$

Similiarly, calculations can be performed for all geometries and fuel loadings. The results of these calculations are given in Table D.IV.1.

TABLE D.IV.1

LEAKAGE AND GAS ABSORPTION

\begin{tabular}{ccccccccc} 
Geometry & Fuel & K & F & A & L & $\frac{\%}{\%}$ Poison & L/Ag \\
\hline 1 & U-233 & 1.00 & 0.405 & 0.444 & 0.576 & 0 & 1.297 \\
1 & U-233 & 1.05 & 0.425 & 0.466 & 0.554 & 5 & 1.227 \\
1 & $U-235$ & 1.00 & 0.412 & 0.542 & 0.508 & 0 & 0.937 \\
1 & U-235 & 1.05 & 0.432 & 0.581 & 0.479 & 5 & 0.850 \\
2 & $U-233$ & 1.00 & 0.405 & 0.443 & 0.562 & 0 & 1.269 \\
2 & $U-233$ & 1.05 & 0.425 & 0.465 & 0.540 & 5 & 1.200 \\
2 & $U-235$ & 1.00 & 0.412 & 0.517 & 0.515 & 0 & 0.996 \\
2 & $U-235$ & 1.05 & 0.432 & 0.551 & 0.481 & 5 & 0.897 \\
3 & $U-233$ & 1.00 & 0.405 & 0.443 & 0.531 & 0 & 1.199 \\
3 & $U-233$ & 1.05 & 0.425 & 0.465 & 0.509 & 5 & 1.124 \\
3 & $U-235$ & 1.00 & 0.414 & 0.510 & 0.491 & 0 & 0.963 \\
3 & $U-235$ & 1.05 & 0.436 & 0.542 & 0.470 & 5 & 0.889
\end{tabular}

